\section{APPOINTMENTS VACANT}

APPLICATIONS are invited for the following appointments on or before the dates mentioned:

MAP CURATOR (preferably geography graduate with an interest in maps and bibliographic work) IN THE DEPARTMENT OF GEOGRAPHY - The Registrar, The University, Leeds, 2 (August 16).

RESEARCH DEMONSTRATOR IN ANIMAL NUTRITION - The Registrar, The University, Leeds, 2 (August 20)

ADMINISTRATIVE ASSISTANT (man or woman, preferably with some familiarity with the notations and terminology of higher mathematics) IN 2 (August 21)

Chemist of Brochemist with the New Zeajand Medical Research Councr, to join its research group at the University of Otago Medical School, Dunedin, working on the metabolism of fatty acids and the relation of diet to atheroma-The Association of Commonwealth Universities (Branch Offlce), Marlborough House, Pall Mall, London, S.W.1; or The Administrative
Officer, Medical Research Council, Box 913, Dunedin, New Zealand (Dunedin, Officer, Medical Research Council, Box 913, Dunedin, New Zealand (Dunedin, August 22)

AsSiSTaNy LECTURer IN Horticulture-The Principal, Yorkshire
(W.R.) Institute of Agriculture, Askham Bryan, York (August 23) (W.R.) Institute of Agriculture, Askham Bryan, York (A ugust 23).
SENIOR DEMONSTRATOR (Ph.D. or near completion of Ph.D.) IN THE SCHOOL OF PHYSICS-The Registrar, University of Melbourne, Parkville, N.2,

ELECTRONICS ENGINEER (able to cope with a wide range of practical prob-
FL lems in varied flelds of physies and electronics, and with a high degree of ENGINEERINa-The Registrar, The University, Manchester, 13, quoting Ref. 154/65/Na (August 25)

RESEARCH AGRONOMIST; a SENIOR LECTURER/LECTURER IN AGRICULTURAL BOTANY; a RESEARCH BOTANIST/PLANT BREEDER; a PLANT INTRODUCTION OFFICER; and a PLANT PATHOLOGIST IN THE INSTITUTE OF AGRICULTURAT. RESEARCH and the FACULTY OF AGRICULTURE, Ahmadu Bello University, Northern Nigeria-The Secretary, Inter-University Council for Higher
Education Overseas, 33 Bedford Place, London, W.C.1 (August 26).

SENIOR LECTURER or LECTURER IN GEOLOGX (Petroleum Geologist) at the University of Queensland, Australia-The Association of Commonwealth Universities

(August 27).

SENIOR RESEARCH ASSOCIATE (with a knowledge of geology or interested in applying chemical techniques to geological problems) IN ORGANIC GEONewcastle upon Tyne, 1 (August 27)

ASSISTANT LECIURER (with an honours degree in psychology or equivalent academic qualifications, and preferably experience in teaching and/or such fields as clinical psychology, educational guidance, vocational guidance, or University of Melbourne-The Association of Commonwealth Universities (Branch Office), Marlbo

and LOMdOn, August 30). in mechanical or electrical engineering and experience in research, and preferably practical experience and experience in teaching at degree level) IN ENGINEERING at the University of Malaya-The Association of Commonwealth Universities (Branch Office), Marlborough

S.W.1 (Kuala Lumpur and London, August 30).

LECTURERS Or ASSISTANT LECTURERS (with a recognized honours degree in mechanical or electrical engingering and experience in research) IN ENGINEERING at the University of Malaya-The Association of Commonwealth Universities (Branch Office), Marlborough

ASSISTANT LECTURER IN THE DEPARTMENT OF BIOCHEMISTRY-The Secretary, The University, Edinburgh (August 31)

KEFPER (with a good honours degtee) of PREHISTORY-The Director, Rhodes-Livingstone Museum, P.O. Box 498, Livingstone, Zambia (August 31 .

ASsistant (graduate in medicine or science) IN THE DEPARTMENT OF

BACTERIOLOQY, Queen's College, Dundee-The Secretary, University of St.
Andrews, c/o Queen's College, Dundee (September 1).
LECTURER (nuclear chemist/physicist) IN THE DEPARTMENT OF PHYSICSLECTURER (nuclear chemist/physicist) IN THE DEPARTMENT OF PHYSICS-
The Assistant Registrar (Science), The University of Birmingham, Birmingham, 15, quoting Ref. P/N (September 1).

LECTURER (science graduate) IN BACTERIOLOGY, Queen's College, Dundee -The Secretary, University of St. Andrews, c/o Queen's College, Dundee (September 1)

LECTURER (with some basic training in clinical pathology such as is required for the Primary M.C. Path.) IN BACTERIOLOGY-The Secretary, The University, Edinburgh (September 1).

HORTICOLTURIST (with qualifications equivalent to a pass degree or the Royal Horticultural Society's final diploma, and an interest in applied entomology and in other topics relating to crop pests) IN THE DEPARTMENT OF AGRICULTURAL $\triangle$ ND FOREST ZOOLOGY, to manage the plots and experiment of Agricultural and Forest Zoology, University College of North Wales, Bangor, North Wales (September 3).

SENIOR LEOTURER (with a Ph.D. in physics, or equivalent in research publications, and some university teaching experience) IN PHYSICS at the University of Queensland, Australia-The Association of Commonwealth
Universities (Branch Office), Marlborough House, Pall Mall, London, S.W.1 (September 3).

SENIOR LECTURERS (2); and LECTURERS/ASSISTANT LECTURERS (with at least a good honours degree with suitable teaching and research experience) tion of Commonwealth Universities (Branch Office), Marlborough House, Pall Mall, London, S.W.1 (Kuala Lumpur and London, September 6).

Assistant IECTURer IN THE DEPARTMENT OF Medical PHYSICS-The ASSISTANT LECTURER IN THE DEPARTMENT OF MEDICAL PHYSICS-The
Secretary, Royal Free Hospital School of Medicine (University of London), Hunter Street, London, W.C.1 (September 7 ).

PoST-Doctoral RESEARCH ASSISTANT IN The DEPARTMENT OF CHEMISTRY for investigations concerning the synthesis and study of organometallic compounds containing fluorocarbon groups, in collaboration with Dr. R. D. Chambers-The Registrar and Secretary, University of Durham, Old Shire Hall, Durham (September 10)

Senior LecturkR/Lecturer in NUMerical Mathematics; and a ProGRAMMER IN THE COMPUTING CENTRE, University of New England, Armidale, New South Wales, Australia-The Association of Commonwealth Universities (Branch Office), Marlbor

London, September 10). Ph.D. degree or postgraduate experience of equivalent standard and duration supported by satisfactory evidence of research ability, and preferably previous experience in the fleld of fungal biochemistry) IN THE BIOCHKMISTRY SECTION of the Division of Plant Industry, Commonwealth Scientifle and Industrial Research Organization, Canberra, A.C.T., Australia, to initiate studies on the biochemistry of spore germination with particular reference to Peronspora tabacina (Blue Mould) in tobacco-Chief Scientiflc Liaison Officer, Australian
Scientific Liaison Office, Africa House, Kingsway, London, W.C.2, quoting Appointment No. 130/723 (September 11).

LECTURER IN VETERINARY PHYSIOLOGY - The Secretary, Trinity College (University of Dublin), Dublin, Republic of Ireland (September 13). LECTURER/SENIOR LECTURER IN ARRONAUTIOA FNGINEERING at the
University of Sydney, Australia-The Association of Commonweaith Universities (Branch Office), Marlborough House, Pall Mall, London, S.W.1 (Australia and London, September 15).

LECTURER IN CYBERNETICS IN THE DEPARTMENT OF APPLIED PHYSICAL IENCES-The Registrar, Room 22 (O.R.B.), The University, Reading September 18).

LECTURERS (3) IN GEOGRAPHY at the University of Canterbury, Christ(Branch Office), Marlborough House, Pall Mall, London, S.W.1 (New Zealand and London, September 24).

LECTURER IN THE DEPARTMENT OF PSYCHOLOGY, University of Western Australia-The Association of Commonwealth Universities (Branch Office), tember 25 ).

LECTURER/SENIOR LECTORER (preferably specialist in the fields of chemical or process metallurgy) IN METALIURGY at the University of Newcastle, New South Wales, Australia-The Association of Commonwealth Universities London, September 30 ).

RESEARCH ASSISTANT (with a degree in zoology or in forestry, and preferbly previous experience in research involving fleld studies) to work with the

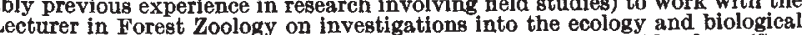
control of foreign insects-The Secretary, The University, Aberdeen (Sep-

CHAIR OF GEOGRAPHY at the University of Otago, Dunedin, New Zealand borough House, Pall Mall, London, S.W.1 (New Zealand and London, October 15).

Chair of Genetics-The Registrar, University College of Swansea, Singleton Park, Swansea (October 30).

SCIENTIFIC OFFICER (preferably specializing in biochemistry, animal genearch Institute Batu Berendam, Malacca, Mar, Tropical Fish Cult

AGRICDIJURAL ChMIST (national of the United Kingdom or the Republic of Ireland, with an honours degree in chemistry and a reasonable amount of experience) IN MALA WI, to organize and control a fairly large chemical laboratory working on various problerns connected with the development of agriculture - The Appointments Officer, Ministry of Overseas Development,
Room 301, Eland House, Stag Place, London, S.W.1, quoting Ref. RC 213/ $134 / 06$.

CHEMrsT (with a pass degree or equivalent qualification, and preferably previous experience in handling radioisotopes) for interesting work on the preparation of short-lived radioisotopes from the cyclotron-The Director, Road, London, W.12.

ELECTRONIC SPECIALIST (with experience of transistor techpiques) IN THE DEPARTMENT OF VETERINARY PHYSIOLOGX, to take charge of the Electronic Workshop-The Secretary, University of Edinburgh, Old College, South GRADUATE RESEARCH ASsistant (preferably with experience in the field of tissue culture) to work in an organ culture laboratory-The Secretary, St. Mary's Hospital Medical School, Paddington, London, W.2.

LECTURER or ASSISTANT LECTURER Or (exceptionally) SENIOR LECTURER Sussex, Stanmer House, Stanmer, Brighton, Sugsex.

Lussex, Stanmer House, Stanmer, Brighton, Sugsex.
LECTURER or ASSISTANT LECTURER (preferably with research interests in forensic chemistry, toxicology or enzymology) IN CHEMISTRY-The Secretary, London, N.W.1.

RESTARCH ASSistant IN THE DFPaRTMENT OF Chemistry AND BIOLOGY, to assist in research on the nutritional aspects of smoking - The Secretary, Welsh College of Advanced Technology, Cathays Park, Cardiff.

RESEARCH ASSISTANT (with a diploma in technology, a degree or their equivalent) IN THE PHYSICS DEPARTMENT, to work on magnetic and related properties of materials over a wde range of temperatures-The Academic Registrar, Loughborough
shire, quoting Ref. 33/AF.

RESEARCH ASSISTANT (with a good honours degree in animal phygiology or zoology or an equivalent qualiflcation, and preferably an interest in biochemistry) IN THE PHYsIology DEPARTMENT, for an investigation of blood levels of oxytocin in relation to reproduction and lactation-The Secretary, Reading, Berkshire, quoting Ref. 64/N/16.

RESEARCH ASSISTANT (with a good honours degree in psychology) IN THE RESEARCH ASSISTANT (with a good honours degree in psychology) IN THE DEPARTMENT OF PSYCHOLOGY for an investigation of associative aspects of
human verbal learning-The Deputy Secretary, The University, SouthampRESEARCH ASSISTANT (with qualifications in physics or chemistry) IN THE DEPARTMENT OF CHEMISTRY, to work on dielectrics with Dr. Mansel Davies -The Registrar, University College of Wales, Aberystwyth.

RESEAROF LRCTURER IN CUINIOAL PSYCHOPHARMACOLOGX-The Secretary, Trinity College (University of Dublin), Dublin, Republic of Ireland.

SENTOR II T haematology)-The Secretary, Birmingham and Midland Eye Hospital, Turch Street, Birmingham, 3. tary, Royal Holloway College (University of London), Englefleld Green, Surrey.

\section{REPORTS and other PUBLICATIONS}

\section{Great Britain and Ireland}

Cement and Concrete Association. Report for the year 1964. Pp. 116. Annotated Bibliography on the Creep and Shrinkage of Concrete. Pp. 70. 1965 .

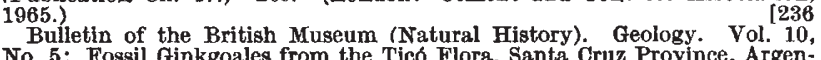
No. 5: Fossil Ginkgoales from the Ticó Flora, Santa Cruz Province, Argentina. By Sergio Archangelsky. Pp. 119-137+5 plates. 288 . Zoology.
Vol. 12, No. 7: A Review of the Fiopoid and Clupeoid Fishes of the Red 